DOI : 10.24260/khatulistiwa.v8i1.1273

\title{
EDUCATIONAL VALUES IN SAPRAHAN TRADITION IN THE MALAY COMMUNITY OF SAMBAS DISTRICT
}

\author{
Dendy Ramadhan \\ Institut Agama Islam Negeri Pontianak \\ Email: dendydendy503@gmail.com
}

\section{HIGHLIGH}

- $\quad$ Educational Values in the Tradition

- Saprahan Tradition

- Sambas Malay People

\section{ARTICLE HISTORY}

$\begin{array}{lll}\text { Submitt } & : & 05 \text { Mar } 2018 \\ \text { Revision } & : & 24 \text { Apr } 2018 \\ \text { Revision } & : & 2 \text { May } 2018 \\ \text { Minor } & & \\ \text { Accepted } & : & 5 \text { May } 2018 \\ \text { Published } & : & \text { 01 Jun } 2018\end{array}$

\section{ABSTRACT}

This article discusses the local wisdom of the Malay culture of Sambas Regency that is the Saprahan tradition. The saprahan tradition is derived from Sambas Malay culture's, the core activity of it is eating together which is done at big events such as marriage, salvation, and so on. In eating together, each group consists of 1 to 6 people in one saprahan, then a tarup is made. Tarup is a place that is used at important events filled with illegal activities for men and eating saprahan. This tradition contains values that are in line with the value of Islamic education. The community is taught the value of togetherness, good relations, removing ego, willingness to share, friendliness, ethics, and self-esteem.

Keyword : $\quad$ Saprahan, Local Wisdoms, Value of Islamic Education, Malay Sambas.

\section{C2018 Khatulistiwa All Rights Reserved}

DOI: $10.24260 /$ khatulistiwa.v8i1.1273

Educational Values in Saprahan Tradition in The Malay Community of Sambas District
KHATULISTIWA: Journal of Islamic Studies

Vol. 8, No. 1. March 2018 


\section{A. INTRODUCTION}

The cultural diversity of Indonesia is very rich and diverse . Wealth includes regional language, ethnicity and customs. Every archipelago has its own identity or characteristic in each local area by showing its existence. Indonesia has its motto, Bhinneka Tunggal Ika, it means variety in diversity. Indonesia has a cultural characteristic that is full of local cultural values.

Culture is one that is owned by every individual human being and every particular group by showing the accent of language, models of dress, behavior, habits, traditions and so forth. Culture becomes a unity that cannot be separated from the human character.

The culture of a community has a unique wisdom that can be interpreted as wisdom in the traditional culture of society. Wisdom in the broad sense is not only cultural norms and values, but also all elements of ideas, including those which have implications for technology, health care and aesthetics. In addition, it also includes, as a manifestation of local wisdom, various patterns of action and aspects of culture (Sedyawati in Prasodjo, ZH, 2017: 199).

Suparlan in Nashir, H, (2013: 32) states that culture as a human knowledge system is clues, recipes, plans and strategies consisting of cognitive models that are sourced from and enveloped by values which lives in the ethos and the collective mind of man, whose use by the perpetrators to interpret and deal with their environment is done selectively.

Culture in everyday life is a mode of action (a model for action) as well as a mode of action in the collective life of humans, so that what should proceed with what is actually, both in the form of similarities and differences (Nashir, H, 2013: 33) .

The form of culture as a supporter of the value of life is at least three kinds, namely: first, as a complex of ideas, thoughts, ideas, values, norms, regulations and so on all it reflects the mind that emits the values believed by the supporting community; second, as a complex behavior / human behavior activity in a patterned society that all show the existence of a value held by him and; third, objects produced by human beings from a community concerned (Muslich, M, 2014: 73).

History has noted that Islam has long been in the Malay realm. Malays accept Islam not only related to the system of belief and ritual, but also the cultural elements brought

KHATULISTIWA: Journal of Islamic Studies

Vol. 8, No. 1. March 2018
DOI: $10.24260 /$ khatulistiwa.v8i1.1273

Educational Values in Saprahan Tradition in The

Malay Community of Sambas District 
with it such as science, Sufism, writing, art and so on. Although honestly different, such as trade, marriage, Sufism, education and art, the entire process of acceptance is easy, without coercion and violence, especially war. After accepting Islam, they generally attempted to adapt the custom to the will of Islamic trade (Abror, A, 2011: 181).

According to Hasbullah (2014: 1) Malay culture that has been touched by Islam carries out a process in its implementation. Malay culture is very thick with Islamic characteristics. The same thing was also expressed by Suparlan in Hasbullah (2014: 2) which stated "The symbol of Malay culture which until now has been recognized as a reference for Malay identity is Islam, Malay, friendliness and openness".

At least there are eight factors that cause Malays to identify themselves and their culture with Islam. First, trade factors; Second, marriage, which is between Muslim immigrants and indigenous women in the early stages of the arrival of Islam; Third, political factors such as the withdrawal of Hindu and Buddhist kingdoms such as Majapahit and Sriwijaya; fourth, the factor of cultural emptiness after the collapse of Srivijaya Buddhism in the Malay archipelago; Fifth, the presence of Sufi scholars or faqir with the tariqat they lead; sixth, islamization is indigenous kings by Sufi scholars or Sufism experts; Seventh, the use of Malay as the language of the spread of Islam and the language of instruction in Islamic education institutions; Eight, the emergence of a new intellectual tradition in the Malay kingdoms as a result of the proliferation of Islam. (Huda, K, 2016: 78-79).

Undoubtedly, the majority of Malays religion is Islam. In its implementation, whether or not implementing Islamic teachings as a whole or not such as carrying out prayers , fasting, zakat, hajj and other good deeds and so on.

\section{B. METHODS}

This article is to discuss the culture entitled "Local Wisdom in the Tradition Saprahan In Sambas Regency Malay Society Perspective of Islamic Values Education. The author uses qualitative methods, as explained by Sugiyono (2016: 15) that qualitative research methods are used to examine natural object conditions, where the researcher is a key instrument, purposive and snowball sampling, data collection techniques using triangulation, data analysis is indictive / qualitative and the results emphasize the meaning rather than generalization.

KHATULISTIWA: Journal of Islamic Studies Vol. 8, No. 1. March 2018
DOI: $10.24260 /$ khatulistiwa.v8i1.1273

Educational Values in Saprahan Tradition in The Malay Community of Sambas District 
While the approach that the researcher uses is ethnography. Creswell, JW (2014: 125) explains that ethnography focuses on groups that have the same culture. The same cultural meanings are like behavior, beliefs, language and values. The community group that the researchers studied was the Sambas Malay community, West Kalimantan.

\section{Islamic Education Value}

Value in English is ' value'. Values are included in the field of philosophical studies, namely philosophy of values. The term value in the field of philosophy is used to indicate something abstract, which means worlh (worth) or goodness (goodness) (Sumihara, 2012: $38)$.

The values in human life are very diverse, of course, many things are considered important when viewed from different aspects or in the eyes or background of each person as in physical material aspects such as the economy, politics, society, service industry and others. Religion or belief has the most important vision that is education about values. Values in various points of view of a particular religion will lead to the improvement and regularity of the human order, both for the perpetrators of value and for other people, other beings (Aziz, A, 2013: 111).

Value is something that is valuable, quality, shows quality and is useful for humans. Something that is valuable means that something is valuable or useful for human life. Value is interpreted as the realization of human consciousness as a mindful being that shows its dignity. With this level of awareness of values, human dignity remains sublime or may be the opposite (Sumihara, 2012: 38) .

According to Milton and James Bank in Sarjono (2005: 136) value is a type of trust that is within the scope of a belief system, in which a person must act or avoid an act or something that is appropriate or inappropriate to do, possess or trust.

Thus, value is a prefect that is reflected in a person's behavior, so he does or does not do something. In this connection, value is the concept, attitude and belief of someone towards something that is considered valuable by him (Sarjono, 2005: 136).

Meanwhile education according to John Dewey in Muslich, M, (2014: 67) is the process of forming fundamental intellectual skills towards nature and fellow humans. The purpose of education is to make the younger generation the successors and heirs of the

KHATULISTIWA: Journal of Islamic Studies Vol. 8, No. 1. March 2018
DOI: $10.24260 /$ khatulistiwa.v8i1.1273

Educational Values in Saprahan Tradition in The Malay Community of Sambas District 
nation who can live and practice the values or norms in society by understanding and living them.

According to Muslich, M, (2014: 69) education is the process of internalizing culture into a person and society so that people and society become civilized. Education is not only a mean of transferring knowledge, but more broadly, namely as a mean of civilization and distribution of values (enculturation and socialization).

Furthermore, in law number 20 of 2003 concerning the national education system (sisdiknas) states that education is a conscious and planned effort to realize the atmosphere and learning process and learning process so that students actively develop their potential to have religious spiritual power, control self, personality, intelligence, noble character and skills needed by him.

In this case education as an effort to change concerning aspects of human life requires references as a source and reference in carrying out the process and to achieve the goals it aspires to (Maarif, MS, 2015: 168).

Islamic education is very important as an effort to grow and familiarize in developing the potential that exists in every human being to have noble and responsible character.

Based on the above opinion it can be concluded that Islamic education is physical and spiritual guidance to the community based on the Qur'an and hadith both individually and collectively in forming individuals into human beings who have a high degree according to God's measure.

Islamic education as a spiritual, moral, intellectual and social process that seeks to guide humans and give them values, principles and ideal examples in life that aim to prepare for the afterlife (Hasan Langgulung in Kurniawan, S , 2015: 21).

\section{RESULT AND DISCUSSION}

\section{Sambas Malay Saprahan Tradition}

Saprahan tradition is one of the habits of the people of Sambas Regency in eating together in one place at weddings, salvation and other events and sitting together both adults and children and separated seating for both men and women. Everything gathers in the tarup . Tarup which is called a tent, this term is a characteristic of Malay.

KHATULISTIWA: Journal of Islamic Studies

Vol. 8, No. 1. March 2018
DOI: $10.24260 /$ khatulistiwa.v8i1.1273

Educational Values in Saprahan Tradition in The Malay Community of Sambas District 
During the important events Tarup (tent) is usually carried out by residents of the local community who are coordinated by the Chairperson of the RT together to build and make it with materials such as boards, bamboo, wood, ropes, fabrics, nails and tarps measuring $25 \mathrm{~m}$ or 30 meters in length as needed.

In addition, temporary buildings for cooking stations, dishwashers, and installation of water pumps are used as sources of supplies for washing dishes and so on. When there is event such as wedding, the host hires special cooks from among women about $7-8$ people and they are paid or unpaid even a dishwasher. They have a union and made special clothes like uniforms.

Seating on tarups is usually on the floor of the board covered in plastic mats or rugs. Tarup places are filled by selected people and have 3 parts, namely, the first tarup for men who have important positions such as Pak Haji (Hajj men), officials, and community leaders and ordinary people separately.

The second tarup is for women such as Mak haji (hajj women/ the wife of religious leaders), officials, and community leaders and ordinary people separately. The third Tarup are intended other guests. Clothes used by men who have important positions are songkok haji (the cap of hajj), suit, sarongs, robes, and turban. All the guests seem to be happy since they gather together and chat each other to enjoy it. Furthermore, one person who guides, arranges and fills the event is usually referred to Pak Labay or better known now is the host.

Yusriadi (2015: 88) explained that when the male get invited to came to the ceremony, party or big meal, they were wearing Sambas Malay clothing, namely dabbal clothes. Dabbal shirt means a suit. A suit is an outer garment, a shirt, paired with a sarong and cap. Sometimes they also wear trousers paired with a cloth; namely the type of holster wrapped around the waist.

Invited guests are welcome to sit in the tarup and are served soft food and drinks such as coffee or more practically mineral water and the food is sponge cake or layer cake cut and wrapped in plastic. At the Saprahan ceremony, people make a group that consisting of 6 people sitting cross-legged on the board.

The food menu that is served is white stew / chicken opor, pickled cucumber, beef stew, fried chili sauce filled with potatoes, petai, and meat cut into small pieces and also a bowl of rice. Then the host invited men first to enjoy food afterwards for women. Then the

KHATULISTIWA: Journal of Islamic Studies Vol. 8, No. 1. March 2018
DOI: $10.24260 /$ khatulistiwa.v8i1.1273

Educational Values in Saprahan Tradition in The Malay Community of Sambas District 
invited guests washed their hands in the space provided and ate together using their hands while chat each other. The eating ethic of the saprahan tradition is before and after eating reading prayers and shalawat.

\section{The Value of Islamic Education in the Saprahan Tradition}

The values of Islamic education in the tradition of the Sambrahan of the Malay community of Sambas district are firstly, the simplicity that eating Besaprah by sitting together on the floor which is served the food menu provided. Secondly, togetherness and kinship that create friendship between fellow human beings both officials and ordinary people by interacting with one another. Thirdly, the unity makes unifying in society.

Meanwhile the values of Islamic education in the tradition of the Sambas Malay community were explained and expressed by Wahab, A, (2017: 393-394) as follows:

The first value is togetherness. Togetherness means collective efforts made by several people or groups of people in achieving certain goals. In the tradition of the Sambas Malay community, the value of togetherness will be seen in guests and people attending. It was also seen from the sitting position and the completion of the meal.

The second value is intimacy and good relationships. Intimacy and good relationships mean an effort to initiate interaction by communication, creating social and emotional ties. In the tradition of Sambas Malay society, such as party weddings, there is an effort to initiate interaction through communication during the meal of Besaprah (do the Saprahan), which in turn builds sustainable relations outside the traditions of the land.

The third value is removing the ego. In the Besaprah tradition, it is expected that all people have an awareness to suppress their desire to control others by communicating and eating food. All must maintain this attitude by giving opportunities to others and trying to create good relations. In tradition, the Sambas Malay Community believed that the main vehicle of communication asked and answered questions.

The fourth value is the desire to share. This value comes after removing the ego. Willingness to share is a personal effort to give others the opportunity to enjoy something to create justice. In the Besaprah tradition in Sambas Malay society, the willingness and effort of everyone in sesaphahan (read: one saprah group) means giving an opportunity to

KHATULISTIWA: Journal of Islamic Studies Vol. 8, No. 1. March 2018
DOI: $10.24260 /$ khatulistiwa.v8i1.1273

Educational Values in Saprahan Tradition in The Malay Community of Sambas District 
others to enjoy even food. So, the willingness to share in the Besaprah tradition is the satisfaction of value in the Sambas Malay community.

The fifth value is hospitality. Hospitality in Malay Sambas community is actualized by communication and interaction during the Besaprah tradition. Hospitality in the MalaySambas community has a major contribution to the Besaprah tradition.

The sixth value is ethics. Ethics is a set of unwritten rules about behavior that is considered good according to society. In the Besaprah tradition, this means that there are some good behaviors according to the Malay-Sambas community that must accompany this tradition. Ethics includes dress code, sitting that is adjusted to how to dress. Ethics Besaprah requires six people in one group to enjoy food.

The seventh value is self-esteem. Self-esteem means values related to one's good reputation in the eyes of the community. In the Sambas Malay community, a person must maintain a good reputation, and also his parents, and family.

Eating Saprahan which has become a cultural custom aims to create friendship and ukhuwah, good relations between people, with a strong spirit of mutual cooperation without distinguishing one's background whether he is an element of officials, leaders or elder people. The eating tradition of Saprahan means "sitting low and standing high" which seems very thick with a sense of togetherness and social solidarity, sitting cross-legged while enjoying various flavors of Malay tastes. (Pridaningsih, DR , 2008) .

\section{CONCLUSION}

The saprahan tradition is derived from Sambas Malay culture, the core activity of it is eating together which is done at big events such as marriage, salvation, and so on. In eating together, each group is consists of 1 to 6 people in one saprahan .

Saprahan is done in a tarup or better known is a tent with a series of activities such as syrakalan, bazanji and others and it is followed by men and women both adults and children separately. This is where eating saprahan has a closeness and the existence of social interaction among others.

The tradition of Saprahan of the Malay community of Sambas district has educational values of Islam that simplicity, Saprahan conducted with ordinary foods and not a luxury. Good relations between the host and the guest are good and mutual respect.

KHATULISTIWA: Journal of Islamic Studies Vol. 8, No. 1. March 2018
DOI: $10.24260 /$ khatulistiwa.v8i1.1273

Educational Values in Saprahan Tradition in The Malay Community of Sambas District 
Self-esteem is maintaining honor and dignity between the host and guests. Hospitality is, when greeting each other, removing ego, eliminating selfishness and prioritizing common interests. Togetherness, is when sitting together between officials and ordinary people despite being separate.

\section{BIBLIOGRAPHY}

KHATULISTIWA: Journal of Islamic Studies

Vol. 8, No. 1. March 2018
DOI: $10.24260 /$ khatulistiwa.v8i1.1273

Educational Values in Saprahan Tradition in The Malay Community of Sambas District 
Aziz, A. (2013). Implikasi Nilai dalam Proses Pendidikan Islam. Ta'allum: Jurnal Pendidikan Islam, 1(1), 111-121.

Abror, A. (2011). Nilai Budi dan Keislaman dalam Pantun Malay Pontianak. Khatulistiwa, $1(2)$.

John, W. C. (2014). Penelitian Kualitatif dan Desain Riset, Memilih diantara Lima Pendekatan. Yogyakarta: Pustaka Pelajar.

Demina, D. (2016). Membumikan Nilai Budaya Lokal dalam Membangun Karakter Bangsa. Ta'dib, 16(1).

Faris, S. (2016). Islam dan Budaya Lokal (Studi atas Tradisi Keislaman Masyarakat Jawa). Thaqafiyyat: Jurnal Bahasa, Peradaban dan Informasi Islam, 15(1), 74-90.

Hasbullah, H. (2014). Islam dalam Bingkai Budaya Lokal. Toleransi, 6(1), 1-15.

Huda, K. (2017). Islam Malay dalam Pusaran Sejarah sebuah Transformasi Kebudayaan Malay Nusantara. Toleransi, 8(1), 78-96.

Koentjaraningrat, K. (1990). Pengantar Ilmu Antropologi. Jakarta: Rhineka Cipta.

Kurniawan, S. (2015). Filsafat Pendidikan Islam. Yogyakarta: Samudra Biru.

Isi, D. (2013). Daftar Isi Jurnal Salam Vol. 15 No. 2 Desember 2012. Jurnal Salam, 15(2).

Ma'arif, M. S. (2015). Nilai-nilai Akhlak dalam Suluk Linglung dan Relevansinya dengan Pendidikan Islam. Empirisma, 24(2).

Muslich, M. (2014). Pendidikan Karakter: Menjawab Tantangan Krisis Multidimensional. Jakarta: Bumi Aksara.

Nashir, H. (2013). Pendidikan Karakter Berbasis Agama dan Kebudayaan. Yogyakarta: Multi Presindo.

Prasojo, Z. H. (2017). Religious and Cultural Existences Within the Communities of Upper Kapuas Riverside of West Kalimantan. Al-Albab, 6(2), 197-214.

Pridaningsih, D. R. (2008). Duduk Sama Rendah, Berdiri Sama Tinggi Nilai-Nilai Budaya Nelayan \& Petambak di Sambas, Kalimantan Barat. Sabda: Jurnal Kajian Kebudayaan, 3(2).

Rosilawati, A. (2013). Ilmu Pendidikan Islam. Pontianak: STAIN Pontianak Press.

KHATULISTIWA: Journal of Islamic Studies Vol. 8, No. 1. March 2018
DOI: $10.24260 /$ khatulistiwa.v8i1.1273

Educational Values in Saprahan Tradition in The

Malay Community of Sambas District 
Sarjono. (2005). Nilai-Nilai Dasar Pendidikan Islam. Jurnal Pendidikan Agama Islam, 2(2), 135-147.

Susmihara, S. (2012). Pendidikan Islam dengan Nilai-Nilai Budaya. Jurnal Adabiyah, 12(2), 168-185.

Syafrizal, A. (2015). Sejarah Islam Nusantara. Islamuna: Jurnal Studi Islam, 2(2), 235-253.

Sunandar, S. (2015). Malay dalam Tantangan Globalisasi: Refleksi Sejarah dan Berubahnya Sistem Referensi Budaya. Khatulistiwa, 5(1).

Sugiyono, S. (2008). Metode penelitian pendidikan:(pendekatan kuantitatif, kualitatif dan $R \& D)$. Alfabeta.

Wahab, W. (2017). Islamic Values of Social Relation in Besaprah Tradition of Sambas Society: The Case of Post-Conflict Malay-Madura in 1999-2017. Walisongo: Jurnal Penelitian Sosial Keagamaan, 25(2), 383-400.

Yusriadi, Y. (2015). Identitas Orang Malay di Hulu Sungai Sambas. Khatulistiwa, 5(1).

Yusriadi, Y. (2017). Berandep, Kearifan Lokal Masyarakat Malay di Dabong, Kubu Raya, Kalimantan Barat. Khatulistiwa, 1 (1).

\section{Interview with:}

Asmadi H.A. (69 tahun). Sambas

Fathan (45). Sambas.

Nurhayati (34), Sambas.

Amalia, A. (23 tahun). Sambas.

Sumiati, (23 tahun)., Sambas.

KHATULISTIWA: Journal of Islamic Studies

Vol. 8, No. 1. March 2018
DOI: $10.24260 /$ khatulistiwa.v8i1.1273

Educational Values in Saprahan Tradition in The

Malay Community of Sambas District 